\title{
コンクリートの打込後の体積変化について*
}

\author{
中条金兵 衛** 近 藤 笑 ${ }^{* *}$
}

\section{On the early Volume Change of Concrete after Placing}

\section{by Kinbē Chūjō and Minoru Kondō}

The Authors measured the early volume changes of concretes which were placed under least friction in the moulds by own method and by devided rapid exact method, and obtained following results.

1) In the cases of Portland Cement of normal properties, the settling amount up to 10 minutes after placing of concrete indicates increased values from $40 \times 10^{-4}$ to $100 \times 10^{1}$ (cowpared with initial unit length) as increasing $W / C$ and slump values. Then the volume change stops for a short time and after 1 2 hours from initial placing, shrinkage due to cement paste in concrete of the order (3 1) $\times 10^{-4}$ reciprocal to $W / C$ and to settling amount, appears.

2) Abnormal Portland Cements which showed the tendency of early craking at concrete building jobs, showed the abnormal settling in above described apparatus in laboratory contınued till 60 minutes after placing of test concrete, and large shrinkage followed the rest period.

\section{1. 緒}

コンクリート打込後の体積变化は一㚇 2 段階に分け て考它られ.才なわちセメントの凝結終了前とその 後に持けるものである.こごとは第 1 段階のものを対 象としている.この初期に蛞ける体積变化に影響を与 える因子は

（1）打ちたてコンクリートが沈下により落ち付く 現象

（2）ブリーデングによる浮_上水の逸出

（3）セメントの水和による物理的，化学的变化 などの外, 高温・通風による乾燥, 型枠のふくらみ,

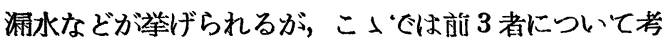
察することにした。

\section{2. コンクリートの初期体榬変化の測定}

コンクリート打込後の軟かい間の体積变化を测定寸 るには種々の力法が考えられるい〜5)，著者らは独自 の考案によつて得た装置をむつてこの一年間研究を続 け，その結果の一部は既に発表した62。

以下装置の原理・構造・方法について述べようと思 3 .

（1）装置牤よび測定方法＼cjkstart装置の大略は Fig.1 と示す通りである.

型 枠 コンクリート圧縮試験用標隼シリンダー 2 個連結または 1 個を用い，内面には油をらすく焦 附し，その上に銅の微粉をまぶす。ささらにその内側に パラフィン紙を 2〜3 枚卷き，その中にコンクリート

\footnotetext{
* 原稿受付 昭和28年11月19日
}

** 日本セメント楼式会社研究所

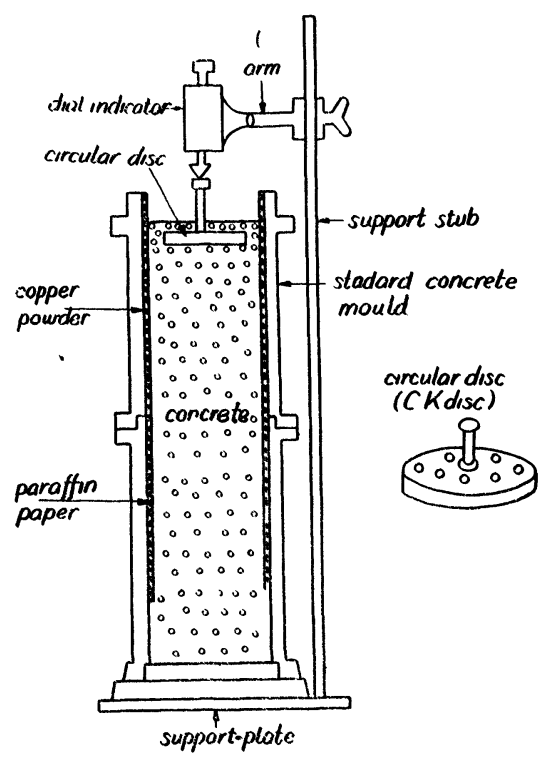

Fig. 1 Apparatus to measure Settling and early Shrinkage of Concrete.

を詰める、銅粉粒子は非常に微細で，镂片状をなし， 被覆力が大きく，また水となじまないので，これが型 枠とパラフィン紙の間に介在することにより摩擦を非 常に小さくし，打込コンクリートの沈下收縮を自由に 行わしめることができる.

型杵側隼の最下部は固定点になるようにこの部分に ば帯状に銅粉もパラフィン紙も施さない。

CKディスク Fig.1の右方に示すように，厚さ $12 \mathrm{~mm}$, 直径 $110 \mathrm{~mm}$ のベークライト製円板の中心に 
真鍮製の棒 $(5 \phi \times 60 \mathrm{~mm})$ を国定し，末端仁直径 12 $\mathrm{mm}$ の小门板を愹揬してダイヤルダージの揬点とし， ベークライト円板にば $9 \mathrm{~mm} \phi$ の円孔 12 個を有し，ブ リーデング水を自由に通過せしめるよらによたあので 要るが，このディスクは非常に有用なのでCKディス クと名づけ愛用した・ディスク全体の雨量は $172 \mathrm{~g}$,

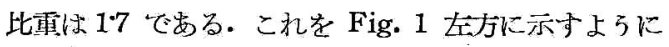
型枠に詰め_ヒげてきたコンクリート中に，上面から 2 4 cm 下方に型枠と中心学合せて埋め込む。ディス クは12個の孔を有寸るのでブリーデング水は自由に通 過する。京た比車は 17 であるからこれを骨材と考急 てタるときコンクリートの作縮と行動をともにすると 思われる。

すなわち比重からいつても，また水平に桩がりを持

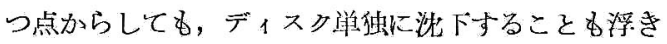
上ることすない。この点を確認するために作用した顕 微鏡に上る方法は後に説四する。

支持台招よびダイヤルグーシ，上記の鉄製型梓は Fig. 1, Fig. 2 の上万と支持台の上に置く.これにな 1 本末たは 2 本の鉄製支柱を固定し，その上部にある アームにダイヤルゲーシをら清する。これの 1 目盛は $1 / 100 \mathrm{~mm}$ である. 型㤾にダイヤルゲージを固定する ことも考えられるが，也メントの水和熱烦つてコン クリートとともに型枠の温度が上晬し次に冷却するた

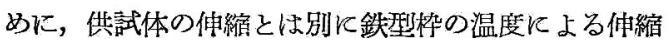

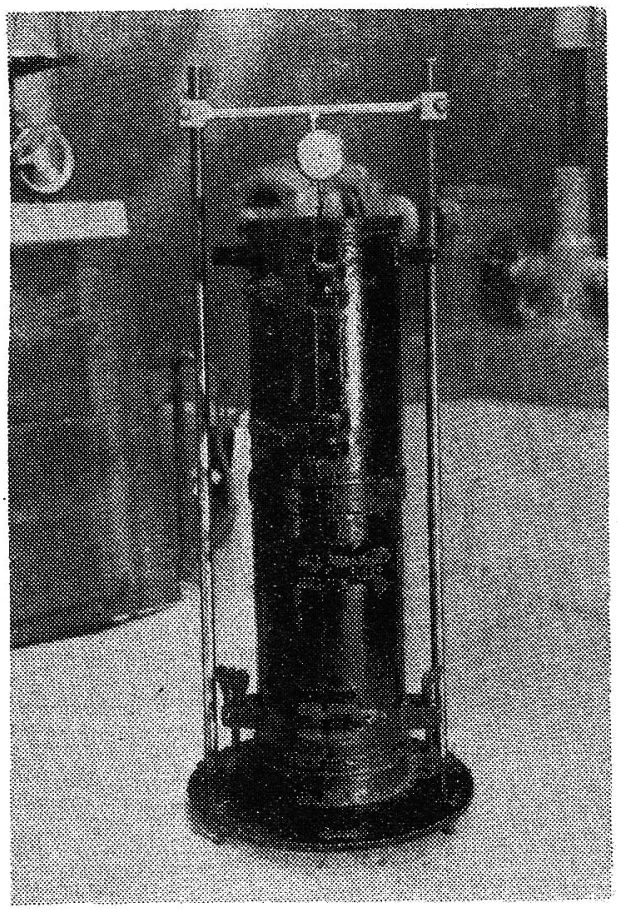

Fig. 2 Apparatus to measure Settling and early Shrinkage of Concute.
によつてゲージが動き，それだけ俱差を生ずる・した がつてこの方法は拯用できないのて，別飞爷柱を立て， これイゲージを取り付けたわけである.

試験材料ミミッー, 装置, 器具類はすべて $20^{\circ}$ $\pm 0.5^{\circ} \mathrm{C}$ の恒温室に置き，測定も同温度で行つた。

顕徽鏡による測定 ダイヤルら゙ージを用いて測定 する場合は CKディスクの頭とゲージのスピンドル を接触せしめて測るが，そのばねの作用のためディス クを多少下方に圧寸る力が偟く・これはディスクの比 雨17 ガコンクリートのそれより小さいために生ずる 浮力とある程度バランスするであろろが，このばねの 作用に上るディ、クの浮沈の有無を磪めて和く必要が ある. したがつてダイヤルがーシによる上記の方法と このだージを取り除き顕微鏡によつてディスクの頭の 運動を測定する方法とを比較した。

両洗の結果は後述するよ5に非常によく一致し，い ずれの方法る正しい結果を与えることを知つた。

ただコンクリートは打終り後直ちに急速に沈下寸る ので迅速に測定を始めなければならない。この点より

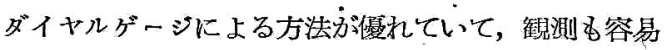
であるから主にこの方洼によつた。

標準型枠 2 連の場合は 6 層に, 単独の場合は 3 層に エンクリートを詰め, そのつぞ鉄棒にてよく㟫き，上 面より梁さ 2〜4 cm の中心部にCK ディスグを粗骨 材に支えられるよらに落ち付かせて埋め込む. コンク リートを打ち終つてのち，できるだけ讯速にダイヤル ゲージをせットして測定にかかる。これ化要する時間 は短、のがよろしく，1〜2 分を装したのみであつた。

\section{3. 実 験 結 果}

（1）ダイナルゲージ法と䡩微鏡法との比較 普 通ポルトランドセメント $330 \mathrm{~kg} / \mathrm{m}^{3}$ 娄使用し，

$W / C=55 \% \quad$ slump $=12 \mathrm{~cm}$

のコシタリートを，上記の装置によつてその棒潗型枠 への打込後の沈下量をダイヤルゲージによる場合々頍 徽籍による測定とを比較したのが Fig. 3 である.す なわら測定を始めから 3 分間の測定值(の印)はダイヤ ルゲージによつて求め, 次にゲージを取り去つてこれ によるばれの作用を止め，CKディスクの頭の動きを 䡩微鏡内のリニアマイクロメータ上:読み取つた測定 值 (OF卬卩)をプロットし，これを曲線で連ねたものが Fig. 3 である。この図に見られるよらに両法による 測定点はよく1つの単純な曲線に乘つている。これは ダイナルル゙ージの足のば权の作用の影響はほとんどな いこと怙よびがイヤルがージ法の正しいととを証明す るすのである.

末た，上と同一のセメントを $330 \mathrm{~kg} / \mathrm{m}^{3}$ 使用し， $W / C=60 \% \quad$ slump $=20 \mathrm{~cm}$ 


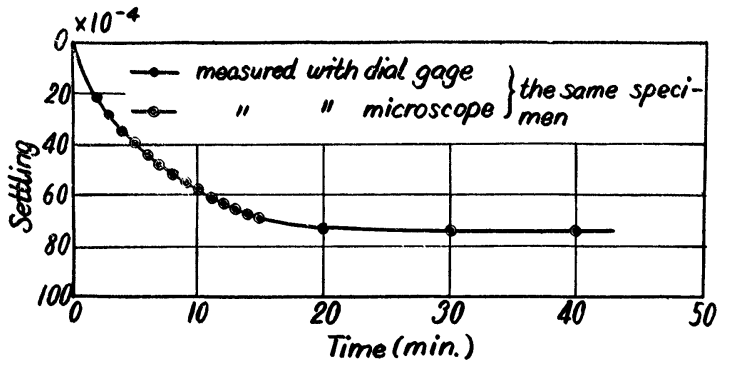

Fig. 3 Settlıng $(W / C=55 \%$, Slump $=12 \mathrm{~cm}$, Normal Cement $=330 \mathrm{~kg} / \mathrm{m}^{3}$ ).

のコンクリートを供試体 2 個に成型し、コンクリート の沈下量を一方に执いてダイヤルゲージにより (Fig. 4 中に - - - - で示す), 他の供試体について顕 微鏡により（Fig.4 中に一○一印）測定したも のが F1g. 4 である.同図に見られるよ5反供試体括 よび測定法が異なつてもほとんど同一の結果が得られ， ダイヤルグージ法は顕微鏡法と同樣の結果を与えるこ とを再び知ることができた。

次に普通ポルトランドセメントを $300 \mathrm{~kg} / \mathrm{m}^{3}$ 使用 L,

$$
W / C=61 \% \quad \text { slump }=12 \mathrm{~cm}
$$

のコンクリートを標隼冈筒供試体 2 個に成型し，それ らの沈下，收縮量を一方の供試体についてダイヤルゲ 一シ法により測定し (O印), 他方の試験体については, 初めの 7 分間はダィナルゲージにより (測定值O印), それ以後は顕徽鏡により（測定值 $\triangle$ 印）測定した結果

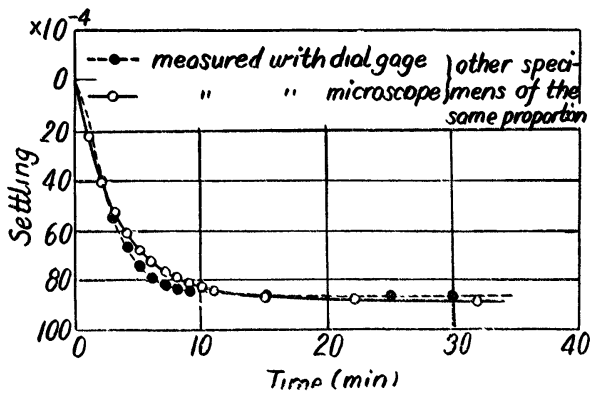

Fig. 4 Settling $(W / C=60 \%$, Slump $=20 \mathrm{~cm}$, Normal Cememt $=330 \mathrm{~kg} / \mathrm{m}^{3}$ ).

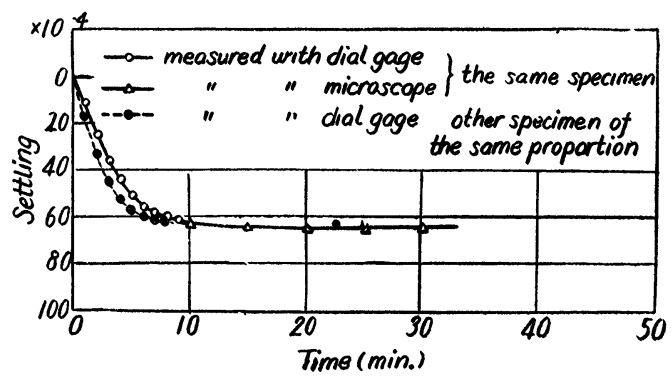

Fig. 5 Settling $(W / C=61 \%$, Slump $=12 \mathrm{~cm}$, Normal Cement $=300 \mathrm{~kg} / \mathrm{m}^{3}$ ).
が F1g. 5 に示されている.眓に見られるように，こ の試験に执いて子両法の妥当性をさらに確め，ダイヤ ルゲージ法つ再現性を知ることができる

以上のよろにCKディスクとダイヤルゲージ使用の 測定法ば正しい結果を示すことが明らかとなつた・こ

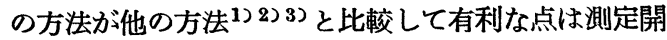
始が非常に早く，コンクリート打込み後 1２ 分の謊 み初め，その後の刻々の変化の測定容易で，打込み 直後から10分以内に劇しく変化するコンクリ.ートの沈 ドを追つて則定するには有力な武器である。

（2）正常なセメントを $330 \mathrm{~kg} / \mathrm{m}^{3}$ 使用，W/C= 50 60\%, slump $=5 \sim 20 \mathrm{~cm}$ の場合 セメントは

Table 1 Properties of Test Portland Cement; Chemical Analysis

\begin{tabular}{c|c|c|c|c|c|c|c|c}
\hline Ig. Loss & $\begin{array}{c}\text { Ins. } \\
\text { Res. }\end{array}$ & $\mathrm{SiO}_{2}$ & $\mathrm{Al}_{2} \mathrm{O}_{3}$ & $\mathrm{Fe}_{2} \mathrm{O}_{3}$ & $\mathrm{CaO}$ & $\mathrm{MgO}$ & $\mathrm{SO}_{3}$ & Total \\
\hline $1 \cdot 10$ & 0.42 & $21 \cdot 84$ & $5 \cdot 61$ & $2 \cdot 94$ & $64 \cdot 62$ & $1 \cdot 70$ & $1 \cdot 19$ & $99 \cdot 42$ \\
\hline
\end{tabular}

Physical properties

\begin{tabular}{|c|c|c|c|c|c|c|c|c|}
\hline Fineness & \multicolumn{2}{|c|}{ Setting } & \multicolumn{6}{|c|}{ Strength $\mathrm{kg} / \mathrm{cm}^{2}$} \\
\hline \multirow{2}{*}{ Blaine } & \multirow{2}{*}{ initiạl } & \multirow{2}{*}{ final } & \multicolumn{3}{|c|}{ Bending } & \multicolumn{3}{|c|}{ Compressicn } \\
\hline & & & $3 d$ & $7 d$ & $28 d$ & $3 d$ & $7 d$ & $28 d$ \\
\hline $3420 \mathrm{~cm}^{2} / \mathrm{g}$ & 1h42m & 2h52m & $27 \cdot 0$ & $48 \cdot 9$ & 66.0 & 104 & 222 & 386 \\
\hline
\end{tabular}

Table 1 亿示すよろな正常な普通ポルトランドセメン トで,これを

cement : $330 \mathrm{~kg} / \mathrm{m}^{3}$, gravel $/$ sand $=1 \cdot 70$ の条件の下に

$$
\begin{aligned}
& W / C=50,55,60 \% \\
& \text { slump }=5,12,20 \mathrm{~cm}
\end{aligned}
$$

と変化せしめた 3 種のコンクリートを打ち，沈下と早 期伸縮とを上記のCKディスクとダイナルグージを使 用する方法によつて測定した結果は F1gs. 6,7,3,8,4, 9 のよろである. それらのらち Figs. 6, 3, 4 は打込後 1〜2 分後からのコンクリートの沈下の状態が水量,

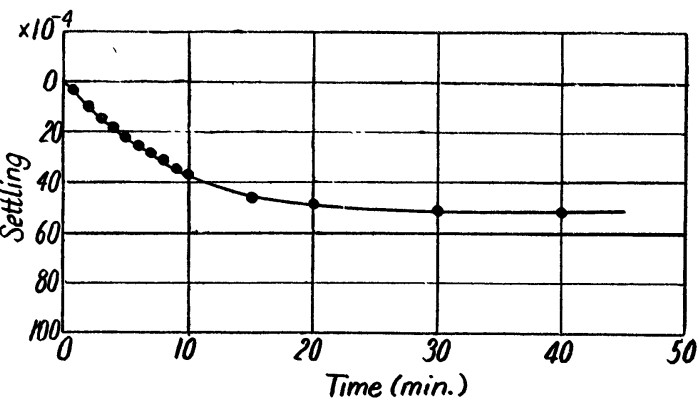

Fig. 6 Settling $(W / C=50 \%$, Slump $=5 \mathrm{~cm}$, Normal Cement $=330 \mathrm{~kg} / \mathrm{m}^{3}$ ). 
スランプの変化に伴つていかなる経過を辿るかを示し， Figs. 7，8，9 は打込みより 5 分以後の主に沈下が終 つてからのコンクリートの伸縮を縦軸のスケールを大 きくして示している.

（3）正常なセメント $300 \mathrm{~kg} / \mathrm{m}^{3}$ 使用，W/C=56 〜 60\%，スランプ 4〜20 cm の場合

(2)の場合と

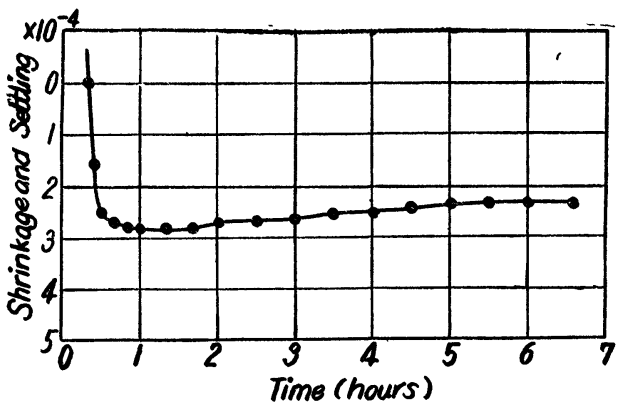

Fig. 7 Shrinkage $(I V / C=50 \%, \operatorname{Slump}=5 \mathrm{~cm}$, Normal Cement $=330 \mathrm{~kg} / \mathrm{m}^{3}$ ).

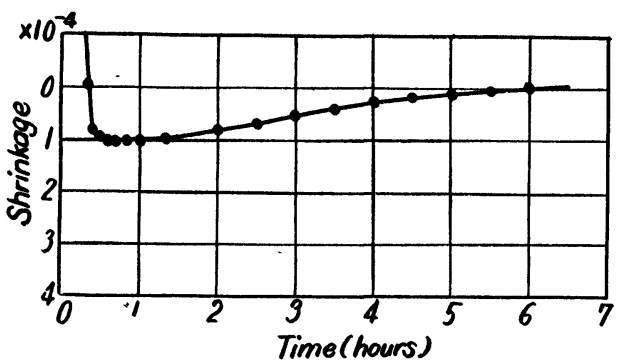

Fig. 8 Shrinkage $(W / C=55 \%$, Slump $=12 \mathrm{~cm}$, Normal Cement $=330 \mathrm{~kg} / \mathrm{m}^{3}$ ).

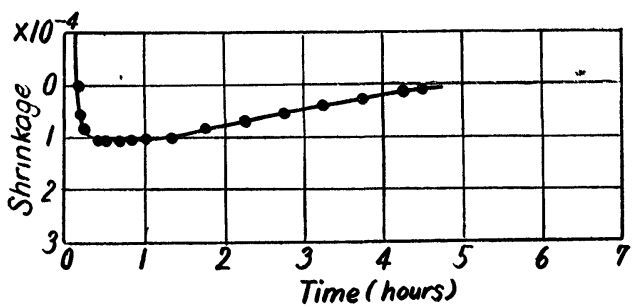

Fig. 9 Shrınkage $(W / C=60 \%$, Slump $=20 \mathrm{~cm}$, Normal Cement $=330 \mathrm{~kg} / \mathrm{m}^{3}$ ).

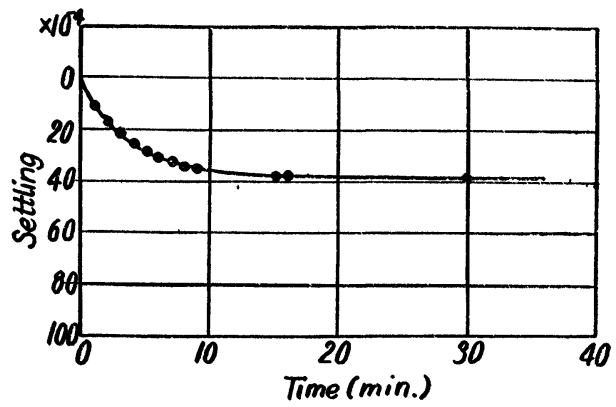

Fig. 10 Setttling $(W / C=56 \%$, Slump $=4 \mathrm{~cm}$, Normal Cement $=300 \mathrm{~kg} / \mathrm{m}^{3}$ ).
同じ正常なセメントを使用し, Cement $=330 \mathrm{~kg} / \mathrm{m}^{3}$

F. M. =砂 : $2 \cdot 10$, 砂利 : 6*83一定とし,

$W / C=56 \%, 61 \%, 66 \%$,

slump $=4 \mathrm{~cm}, 12 \mathrm{~cm}, 20 . \mathrm{cm}$

のように変化せしめて，3種のコンクリートの沈下と 早期伸縮とを上記の装置によつて測定した. Figs. 10, $11 ; 5,12 ; 13 ， 14$ に示す通りである.

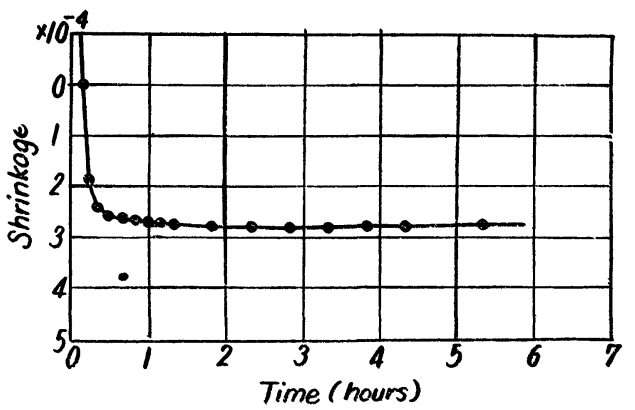

Fig. 11 Shrinkage $(W / C=56 \%, S l u m p=4 \mathrm{~cm}$, Normal Cement $=300 \mathrm{~kg} / \mathrm{m}^{3}$ ).

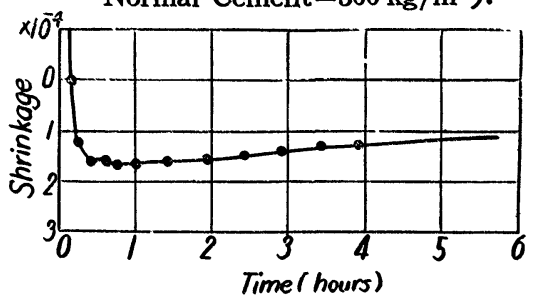

Fig. 12 Shrinkage $(W / C=61 \%$, Slump $=12 \mathrm{~cm}$, Normal Cement $=300 \mathrm{~kg} / \mathrm{m}^{3}$ ).

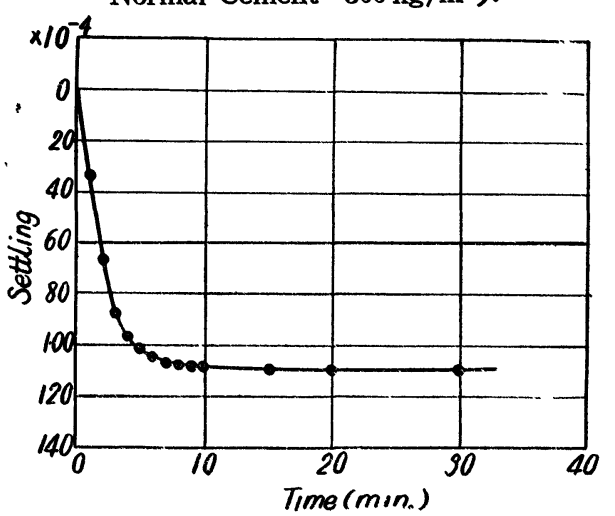

Fig. 13 Settling $(W / C=66 \%$, Slump $=20 \mathrm{~cm}$, Normal Cement $=300 \mathrm{~kg} / \mathrm{m}^{3}$ ).

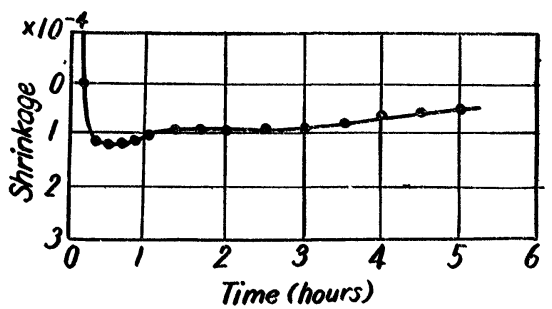

Fig. 14 Shrinkage $(W / C=66 \%$, Slump $=20 \mathrm{~cm}$, Normal Cement $=300 \mathrm{~kg} / \mathrm{m}^{3}$ ). 
Figs. 10, 5, 13 は打込終了後 1 2 分からの沈下の 経過を水量，スランプを上記のよらに変えて測定した 結果で, Figs. 11，12，14 は沈下がほぼ終つた 5 分後 からの圭に仲縮の部分を拡大して揭げてある.

（4）茟築現場で初期龟裂を生じたセメントによる 結果建築現場“゙は各種の条件下に施工されている から，発生した初期角裂がセメントによるるのとは断 言できない場合が多いのであるが，一応そうした現場 から普通ポルトランドせメント $\mathrm{A}$ ，他の現場から普通 セメントBを譲り受けて，それらによつて

$W / C=60 \%, \quad$ slump $=17 \sim 18 \mathrm{~cm}$ gravel $/$ sand $=1.50 \quad$ cement $=323 \mathrm{~kg} / \mathrm{m}^{3}$ のコンクリートとし，上記の装置によつて沈下と伸縮 を測定して放た。これが Figs. 15, 16, 17,18 である. これらと比較するため正常と考えられる普通セメント Cとて上と同よろの条件下，すなわち

$W / C=60 \%$, slump $=13 \mathrm{~cm}$, cement $=323 \mathrm{~kg} / \mathrm{m}^{3}$ のコンクリートの沈下，伸縮の測定結果を Figs. 19, 20 К揭げた。

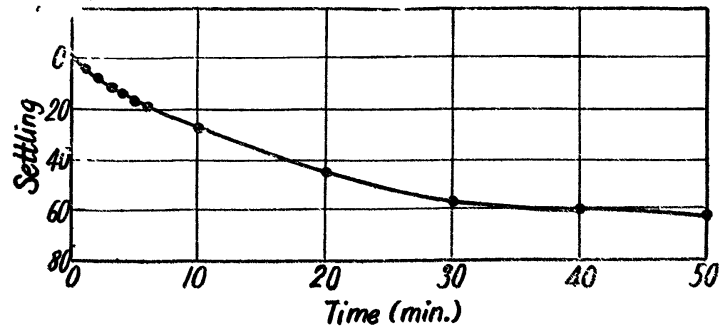

Fig. 15 Settling $(W / C=60 \%$, Slump $=18 \mathrm{~cm}$, Abnormal Cement $A=323 \mathrm{~kg} / \mathrm{m}^{3}$ ).

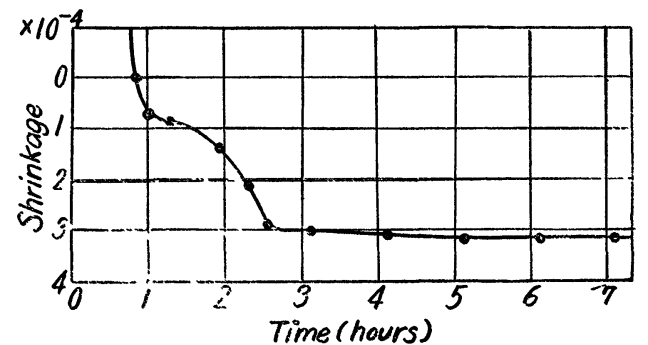

Fig. 16 Shrinkage $(W / C=60 \%$, Slump $=18 \mathrm{~cm}$, Abnormal Cement $A=323 \mathrm{~kg} / \mathrm{m}^{3}$ ).

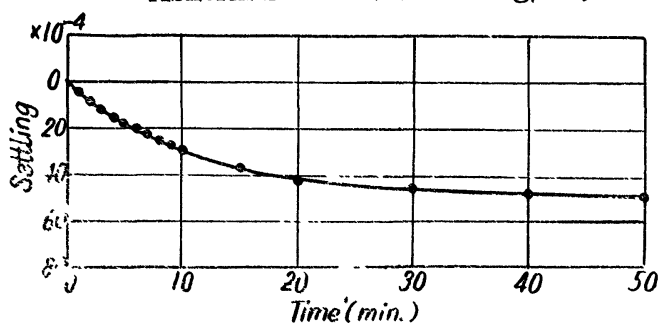

Fig. 17 Settling $(W / C=60 \%$, Slump $=17 \mathrm{~cm}$, Abnormal Cement $\mathrm{B}=323 \mathrm{~kg} / \mathrm{m}^{3}$ ).

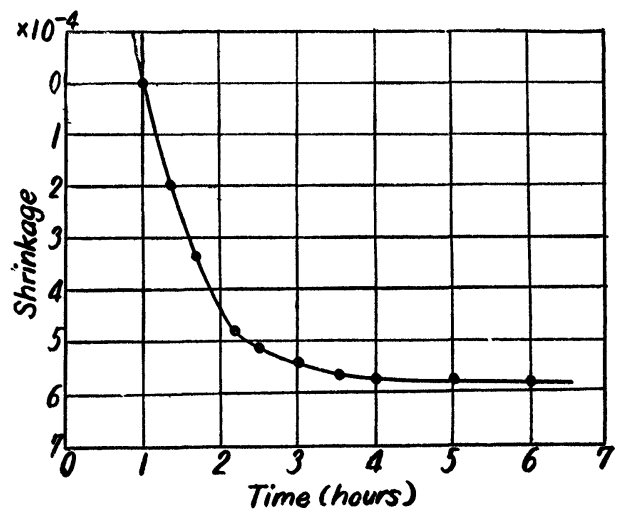

Fig. 18 Shrinkage $(W / C=60 \%$, Slump $=17 \mathrm{~cm}$, Abnormal Cement $\mathrm{B}=323 \mathrm{~kg} / \mathrm{m}^{3}$ ).

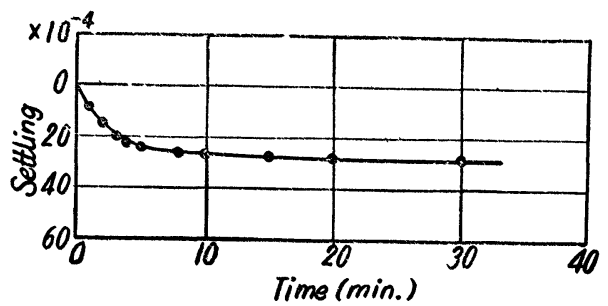

Fig. 19 Settling $(W / C=60 \%$, Slump $=13 \mathrm{~cm}$, Normal Cement $\mathrm{C}=330 \mathrm{~kg} / \mathrm{m}^{3}$ ).

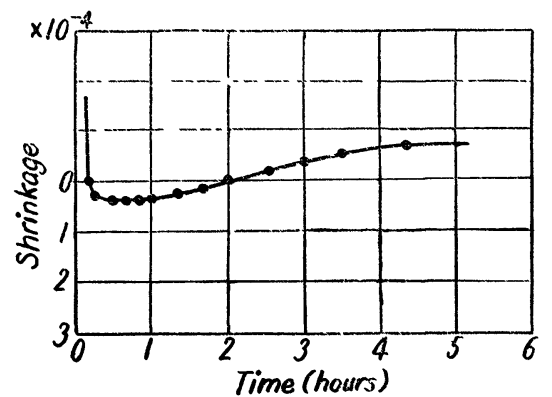

Fig. 20 Shrınkage $(W / C=60 \%$, Slump $=13 \mathrm{~cm}$, Normal Cement $\mathrm{C}=330 \mathrm{~kg} / \mathrm{m}^{3}$ ).

\section{4. 实験結果の娭討}

ヒに測定しふ結果を各図について批判梌討すれは次 のよろである。

(1) Figs. 3, 4, 10, 5, 13 のごとく正常と考えら れる普通ポルトランドセメントの水量 $56 \%$ 以上, セメ ント使用量 $300 \sim 330 \mathrm{~kg} / \mathrm{m}^{3}$ K朔けるコンクリートは, 型忰侧堡の摩擦の少ないとき，打込み後 10〜20分でほ とんど沈下を終えてしま5。これに反し建築現埸で隹 裂の出る䝨间のあつた場合, Figs. 15, 17 に扔いては 50分経䧟後む沈下か流く樣相を品している.

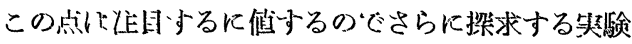
を行つている.

Fig. 6 のごとくW/C=50\%， slump $=5 \mathrm{~cm}$ の場

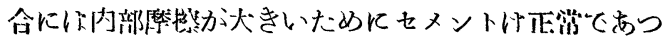

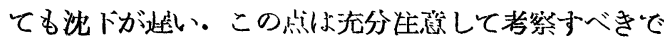


ある.

（2）正常なセメントK怙いては Figs. 7,8,9,11， 12,14 のごとくコンクリート打込後 10２0 分にして 沈下が止り，曲線は一時水平となる。 この点を Rest Point と称することとする.これを越えて打込み後 1 時間ほぞ経てからセメント自身による伸縮の影響が現 われるが，上揭の正常なセメントに怙いてはその絶对 值が小さく，むしろ膨脹を示している。建築現場で宿 裂を発見したケイスに相当する．F1gs. 16，18 亿拗い ては收縮の絶対值も犬きく，また特買の形状を呈して いるものがある.

しかしコンクリートの 10〜60 分間の沈下量が Initial Length 1 亿対し $40 \times 10^{-4} \sim 100 \times 10^{-4}$ であ るのK反して，60分〜 2 時間の仲縮値は正常なコンク

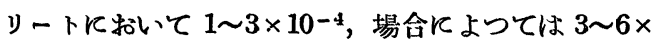
10-4 であつて，沈下量の $1 / 10$ 以下である。これを沈 下と伸縮とを混同してしまつて收縮が大きいと考え， かつ、これはセメントのせいであるとする向きもある が，それは誤りであることが上の奏験結果からいえる のである.

（3）上迈のようКコンクリートの沈下量は非常に 大きいから，鉄筋の择入してある場合その下側にボイ ドを生ずるから，コンクリートの打継ぎ面と鉄筇の個 所との相対的位置には充分住意し，打継ぎ面以鉄湓の 直下で行らか，バイブレーターを用いるか，適当な方 法を講ずべきである。

（4） セメント技術年報（昭和 28 年度）162頁の結 果を再録する. すなわち Fig. 21 は正常なセメント を用い, $\mathrm{W} / \mathrm{C}=60 \%$ 一定とし, スランプを $5 \mathrm{~cm}, 10 \mathrm{~cm}$ $15 \mathrm{~cm}, 20 \mathrm{~cm}$ と変化せしめた場合の沈下，Fig. 22 は Slump $=15 \mathrm{~cm}$ 一定飞保ち，W/C=55\%，60\%，65\% と変化させた場合の沈下である.

Fig. 22 とよつてわかるよろに，沈下と收縮とを混 同している人々が, 水量, 寸なわち $W / C$ が大きいコ ンクリートは收縮が大きいと言つているけれどあ決し てそらではない。この点については別に論ずる予定で あるが，Fig. 21 に示寸よらにW/Cが一定でスラン プの值が大きくなると沈下量を増すことて注意すべき である.

ただしこれは沈下であつて，セメントの收縮によ るあのでないことを再びことわつて特く.

（5）本報の結果およひ結論はすでと説明したよ5 に銅粉とパラフィン紙によつて型枠の内壁の摩擦を極 力少なからしめた場合の時間関保について得られたも のであつて，その点を考慮しない摩擦の大きい昜合か らは有䜤な結諭を得難いと思われる。

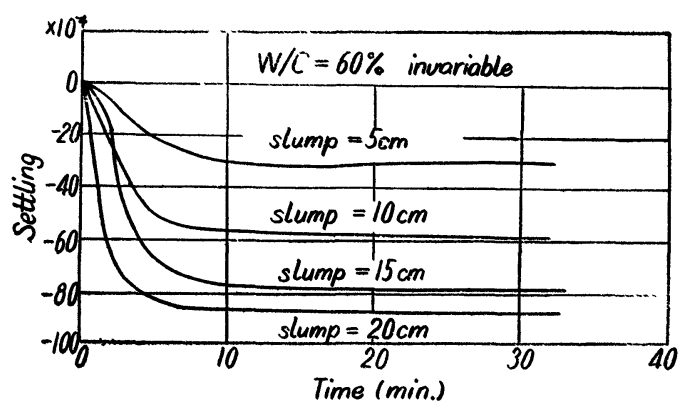

Fig. 21 Settling of Concrete.

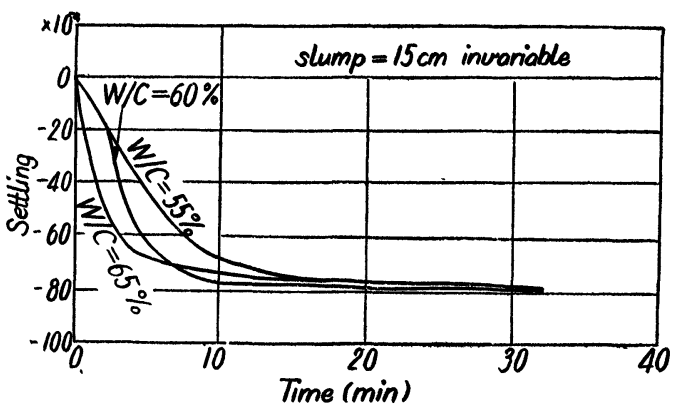

Fig. 22 Settling of Concrete.

\section{5. 要 約}

本報に叔いては打ちたてコンクリートの沈下伸縮現 象の研究結果を述べたものである.

（1）考案したディスクとダイナルゲージをを附属 した装置によつて进速に变化与る沈下量を測定したが， この方法の正しいととは影微鏡法によつて確められた。

(ii）この装置によつて，正常な普通ポルトランド セメントの使用量, 水セメント比，スランプを変化せ しめた場合の沈下，伸縮量を測定し，その経過と程度 を示した。

（iii）建築現場において初期笔裂の傾向を生じたせ メントイて本装置を用いて沈下，伸縮現象を調查した 結果, 上記の正常なセメントに比し沈下が長期に続き， 伸縮にも異常のある特徽を認めた。

(iv）型枠とコンクリートとの摩擦を少なくするた めに特別な方法を用い成功を收めた。

な扣本研究は取締役細井研究所長の御指導により, また永高，樋田氏らの協力によつて行つたものて厚く 感謝の意を表するるのである。

注 : 一

1) 吉四㯖次郎，土本学会誌，Vol. 18, No.8 (1932)

2）吉田彌七，七メント・コンクリート,5月号 (1952)

3) R.E. Davis, 未公否の研究, April, (1953)

4) C.H. Scholer \& E. R. Dawley, ASTM. Proc. (1930)

5）点野俊介，セメント技街年硍，昭和23年 (1948)

6）中條，近滕，セメント技術年战，略利28年 (1953) 